\title{
Our experience of nifedipine as a tocolytic agent in preterm labor ( 24 weeks to 36 weeks 6 days)
}

\author{
Parag Hangekar, Anand Karale, Neelesh Risbud
}

Department of Obstetrics and Gynecology, Smt. Kashibai Navale Medical College and General Hospital, Pune, Maharashtra, India

Received: 05 December 2016

Accepted: 31 December 2016

*Correspondence:

Dr. Parag M Hangekar,

E-mail: paraghangekar@gmail.com

Copyright: () the author(s), publisher and licensee Medip Academy. This is an open-access article distributed under the terms of the Creative Commons Attribution Non-Commercial License, which permits unrestricted non-commercial use, distribution, and reproduction in any medium, provided the original work is properly cited.

\section{ABSTRACT}

Background: Preterm birth is defined as birth between the age of viability and 37 completed weeks of gestation. The aim of this study is to evaluate the safety and efficacy of nifedipine, a calcium channel blocker, as a tocolytic in prolonging duration of pregnancy in case of preterm labor.

Methods: This is a retrospective analytical study conducted in Department of Obstetrics and Gynaecology, SKNMC and GH, Pune, India conducted over a period of one year from June 2014 to May 2015. All uncomplicated, singleton preterm labor cases were given Cap. Nifedipine as tocolytic and Inj. Betamethasone for enhancing fetal lung maturity. Maternal parameters studied were Gravida and Parity, previous history of preterm labor, gestational age at delivery, mode of delivery, side effects. Neonatal parameters studied were weight at birth, APGAR score at birth, complications at birth, NICU admissions, mortality.

Results: Out of total 4478 deliveries from June 2014 to May 2015, 252 women with preterm labor were treated with nifedipine. 214 out of 252 delivered at term with overall success rate of $84.92 \%$. Out of remaining 38 cases, 36 cases delivered as preterm normal deliveries and 2 required Caesarean section. No major side effects observed in mothers receiving nifedipine. As regards neonatal outcome, 12 babies required NICU admission and mortality was of 2.

Conclusions: Nifedipine is safe and effective in prolonging preterm labor and has minimal maternal and neonatal side effects. It eliminates the need for intensive maternal monitoring as required in case of betamimetics.

Keywords: Nifedipine, Preterm, Tocolytic

\section{INTRODUCTION}

Preterm birth is defined as birth between the age of viability and 37 completed weeks of gestation. ${ }^{1}$ The number of preterm births every year is estimated to be 15 million, out of which nearly 1 million die due to birth complications. $^{2}$ India has greatest number of preterm births which is about 3.5 million per year. ${ }^{3}$

Preterm birth is leading cause of perinatal morbidity and mortality. Despite the improvement in survival rates of preterm neonates, they are at increased risk of long-term neurodevelopmental disabilities, and respiratory and gastrointestinal complications. More than three-quarters of premature babies can be saved with feasible, costeffective care, e.g. essential care during child birth and in the postnatal period for every mother and baby, antenatal steroid injections given to pregnant women at risk of preterm labor kangaroo mother care (the baby is carried by the mother with skin-to-skin contact and frequent breastfeeding) and antibiotics to treat newborn infections. ${ }^{2}$ Management of preterm labor includes bed rest, adequate hydration, prophylactic cervical encirclage and use of tocolytic drugs. Although tocolytics have not been shown to improve neonatal outcomes, they can delay preterm delivery long enough for antenatal 
corticosteroids to be administered or for the mother to be transported to a tertiary care facility. ${ }^{4}$ Various tocolytic agents include beta mimetics (ritodrine, terbutaline), magnesium sulfate, prostaglandin inhibitors (indomethacin, ketorolac), calcium channel blockers (nifedipine, nicardipine), nitrates (nitroglycerine), oxytocin receptor blockers (atosiban). ${ }^{4}$

Calcium channel blockers (CCBs) are non-specific smooth muscle relaxants, predominantly used for the treatment of hypertension and are increasingly used as a tocolytic agent for women in preterm labor. ${ }^{5}$ Calcium channel blockers are effective tocolytic agents in preterm labor with comparatively lesser side effects than betamimetics. ${ }^{6}$ One of the Cochrane reviews concluded that calcium channel blockers are preferable to other tocolytic agents in case of preterm labor. ${ }^{7}$ Betamimetics may cause maternal side effects like tachycardia, hypotension, tremor, arrhythmia, myocardial infarction and death due to pulmonary edema. ${ }^{8,9}$ Nifedipine is a dihydropyridine calcium channel blocker which acts act on L-type calcium channels to inhibit calcium influx into myometrial cells. Reduced intracellular calcium concentrations prevent activation of myosin light chain kinase, and thereby myometrium contraction. ${ }^{10}$ It is used as oral dose of 10 - $20 \mathrm{mg}$ every 3-6 hours upto maximum dose of $160 \mathrm{mg}$ in 24 hours. Combination of nifedipine and atosiban has additive tocolytic effect, while combined therapy with betamimetics or $\mathrm{MgSO}_{4}$ should be avoided. ${ }^{11}$

\section{METHODS}

A Retrospective analytical study of use of Nifedipine in preterm labour cases was carried at SKNMC and GH, Pune, India from June 2014 to May 2015. Total 4478 women delivered from June 2014 to May 2015, out of which 468 women experienced preterm labor. 252 among 468 were selected for the study. All preterm labor cases fulfilling inclusion criteria were given Capsule Nifedipine as tocolytic and Injection Betamethasone for enhancing fetal lung maturity.

\section{Drug doses}

- Capsule nifedipine oral 4 doses each of $10 \mathrm{mg}$ given 15 minutes apart for acute tocolysis, followed by Tablet Nicardia Retard (nifedipine sustained released) $20 \mathrm{mg} \quad$ twice daily for next 7 days as maintenance tocolysis. Tablet Nicardia retard was started 12 hours after last dose of capsule nifedipine.
- Injection Betamethasone $12 \mathrm{mg}$ intramuscular 2 doses given 24 hours apart.

\section{Inclusion criteria}

- $\quad$ Singleton pregnancy with gestational age between 24 to 36 weeks 6 days.

- Alive normal fetus.

- Cervical dilatation upto $3 \mathrm{~cm}$.

\section{Exclusion criteria}

- Severe pre-eclampsia and eclampsia.

- Placenta previa, Abruptio placentae.

- Severe intra-uterine growth restriction.

- Multifetal pregnancy.

- Fetal malformation.

- Intrauterine fetal death

- Chorioamnionitis.

- Cervical dilatation $>3 \mathrm{~cm}$, ruptured membranes.

- Hypotension (Blood pressure $<80 \mathrm{~mm}$ systolic/ $<50 \mathrm{~mm}$ diastolic).

Cases were monitored by clinical signs and symptoms, maternal pulse and blood pressure every 30 minutes, uterine contractions, BP charting, non-stress test, daily fetal movement count. The frequency and duration of uterine contractions were monitored by external monitoring with Tocodynamometer and clinically by manual palpation. Patients who were discharged from hospital after successful tocolysis were advised daily fetal movement count, non-stress test once a week and ultrasound growth scan every 2 weeks. Maternal parameters studied were gravida and parity, previous history of preterm labor, gestational age at delivery, duration of prolongation of gestation, mode of delivery and side effects of drug. Neonatal parameters studied were weight at birth, APGAR score at birth, complications at birth, NICU admissions and perinatal mortality.

\section{RESULTS}

Out of total 4478 deliveries from June 2014 to May 2015, 252 women with preterm labor were treated with nifedipine. 214 out of 252 delivered at term with overall success rate of $84.92 \%$. Success rate was found to be better in primigravida $(87.68 \%)$ compared to multigravida $(81.57 \%)$ (Table 1$)$.

Table 1: Success rate of nifedipine.

\begin{tabular}{|l|l|l|l|l|}
\hline & Cases & Delivered at term & Delivered at preterm & Success rate \\
\hline Primigravida & 138 & 121 & 17 & $87.68 \%$ \\
\hline Multigravida & 114 & 93 & 21 & $81.57 \%$ \\
\hline Total & 252 & 214 & 38 & $84.92 \%$ \\
\hline
\end{tabular}


Out of 114 preterm multigravida cases, 22 had history of preterm labor, out of which 18 were successfully prolonged upto term and 4 delivered preterm, with success rate of $81.82 \%$. Out of 38 preterm cases, only 4 delivered within 48 hours.

Overall 34 cases were prolonged for more than 48 hours, while 29 cases prolonged for more than 7 days (Figure 1).

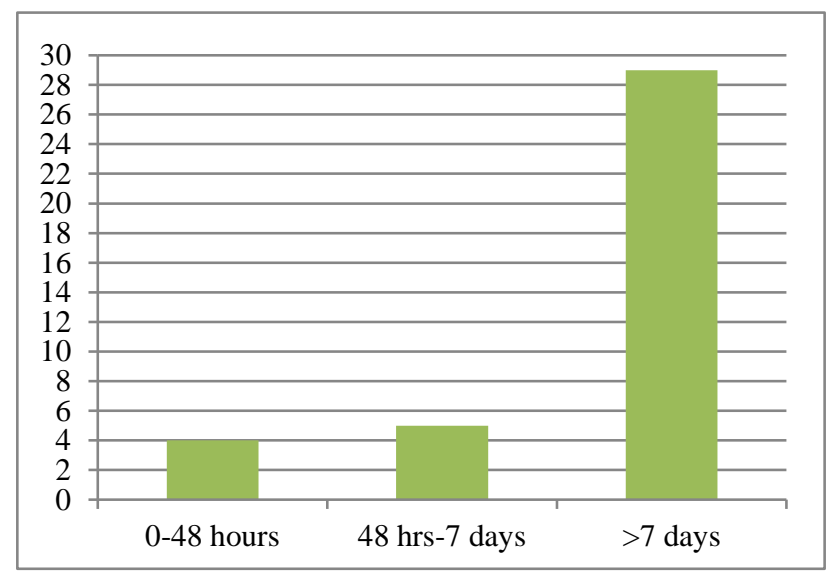

Figure 1: Prolongation of labor.

Success rate in prolongation of pregnancy $>48$ hours was $89.47 \%$ and $>7$ days was $76.31 \%$.

Out of 38 , only $2(5.26 \%)$ cases underwent lower section caesarean section while others delivered by vaginal route. Indication of caesarean section was fetal distress in both cases (Figure 2).

As far as maternal side effects are concerned, 5 women $(1.98 \%)$ complained of headache, 2 (0.79\%) had tachycardia and $2(0.79 \%)$ developed hypotension.

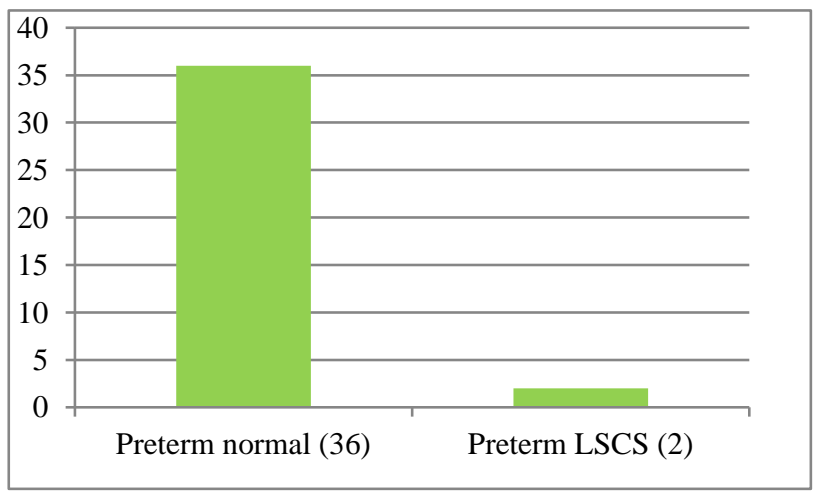

Figure 2: Delivery outcome.

As regards baby weight, $30(78.94 \%)$ out of 38 babies weighed between $2-2.5 \mathrm{~kg}$. Lowest baby weight observed was 900 grams (Table 2).
Table 2: Weight of babies delivered.

\begin{tabular}{|l|l|}
\hline Baby weight $(\mathrm{Kg})$ & Number of babies \\
\hline $0.5-1$ & 1 \\
\hline $1-1.5$ & 2 \\
\hline $1.5-2$ & 2 \\
\hline $2-2.5$ & 30 \\
\hline $2.5-3$ & 3 \\
\hline
\end{tabular}

Out of 38 cases, $12(31.57 \%)$ babies required NICU admission due to prematurity, low birth weight and respiratory depression. 2 babies (5.26\%) succumbed to death (Figure 3).

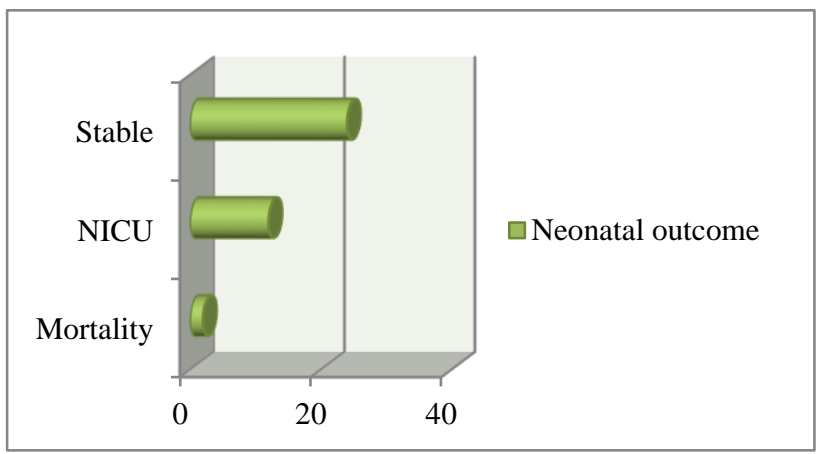

Figure 3: Neonatal outcome.

\section{DISCUSSION}

Lower success rate in multigravida cases can be due to previous history of preterm birth and cervix already becomes patulous in multigravida.

The mean duration of prolongation of pregnancy was 39.4 days. Dhawle et al found it to be 35 days in his study. ${ }^{12}$ Smith et al observed prolongation around 35.2 days. ${ }^{13}$ Nifedipine prolonged pregnancy beyond two days in $80.9 \%$ women and beyond 7 days in $72.1 \%$ cases in a study by Papatsonis et al, whereas, Kashanian et al found the pregnancy prolongation beyond two days to be $75 \%$ and beyond 7 days in $65 \%$ women. ${ }^{14,15}$

Nifedipine causes peripheral vasodilation causing most commonly headache (1.98\%), other side effects being tachycardia, palpitation, hypotension, flushing. Dhawle et al observed headache in $4.7 \%$ cases, tachycardia was observed in $11.6 \%$ cases. Gasper et al noted such side effects in $10 \%$ cases.

Most of the babies weighed between 2-2.5 kg. Tan et al observed neonatal deaths in $1.83 \%$ cases. Veen et al reported a case of severe asymptomatic hypo-tension followed by fetal death after the administration of Nifedipine. ${ }^{16}$ In present case fetal demise was observed to be on higher side $(5.26 \%)$ cases, probably due to less sample size. Nifedipine has not been found to be direct cause of maternal death yet. 


\section{CONCLUSION}

Prevention and proper treatment of preterm labor is essential to reduce perinatal morbidity and mortality, and improve quality of life. An ideal tocolytic should postpone delivery at low costs without maternal and fetal side effects. Although it is difficult to choose first line tocolytic agent among available drugs, calcium channel blockers seem to have better outcome. Nifedipine is safe and effective in prolonging preterm labor and has minimal maternal and neonatal side effects. It eliminates the need for intensive maternal monitoring as required in case of betamimetics. More calcium channel blockers should be studied which will have selective action on myometrium, thus reducing systemic side effects. The ultimate goal of management of preterm labor should not be just to prolong pregnancy but also to improve neonatal outcome and to reduce morbidity and mortality.

\section{ACKNOWLEDGEMENTS}

Authors would like to thank Dr. Gulabsingh Shekhawat (Prof. and HOD), Dr. Neelesh Risbud (Prof. and HOU), Dr. Jyotsna Potdar (Asso. Prof.) Dr. Sameer Darawade (Asso. Prof.) Dr. Ketki Junnare (Asso. Prof.), Dr. Anand Karale (Asst. Prof.), Dr. Ganesh Mhaske (Sr. resident).

Funding: No funding sources

Conflict of interest: None declared

Ethical approval: The study was approved by the Institutional Ethics Committee

\section{REFERENCES}

1. WHO. Managing complications in pregnancy and childbirth- abdominal pain in later pregnancy and after childbirth. 2007.2 Available at: http://apps.who.int/iris/bitstream/10665/43972/1/92415 45879_eng.pdf.

2. WHO Preterm birth fact sheet no. 363. Updated November 2015. Available at: http://www.who.int/ mediacentre/factsheets/fs363/en/

3. Blencowe H, Cousens S, Oestergaard M, Chou D, Moller AB, Narwal R, et al. National, regional and worldwide estimates of preterm birth. The Lancet. 2012;379(9832):2162-72.

4. Haas DM, Benjamin T, Sawyer R, Quinney SK. Shortterm tocolytics for preterm delivery- current perspectives. Int J Women Health. 2014;6:343-9.

5. Flenady V, Wojcieszek AM, Papatsonis D, Stock O. Calcium channel blockers for inhibiting preterm labor and birth. Cochrane Database Syst Rev 2014;5(6):CD002255.

6. Gasper R, Toth JH. Calcium Channel Blockers as Tocolytics: Principles of their actions, adverse effects and therapeutic combinations. Pharmaceuticals (Basel). 2013;6(6):689-99.

7. Papatsonis D, Flenady V, Cole S, Liley H. Calcium channel blockers for inhibiting preterm labor (Cochrane Review). Cochrane Database Syst Rev. 2005;20;(3):CD0044528.

8. Chandraharan E, Sabaratnam A. Recent advances in management of preterm labor. J Obstet Gynecol India. 2005;55(2):118- 24.

9. Raju TN. Epidemiology of late preterm (near-term) births. Clin Perinatol. 2006;33:751-63.

10. Conde-Agudelo A, Romero R, Kusanovic JP. Nifedipine in the management of preterm labor: a systematic review and metaanalysis. Review article. Am J Obstet Gynecol. 2011;204(2):134.

11. Dhawle A, Kalra J, Bagga R, Aggarwal N. Nifedipine versus nitroglycerin for acute tocolysis in preterm labor: a randomised controlled trial. Int J Reprod Contracept Obstet Gynecol. 2013;2(1):61-6.

12. Smith P, Anthony J, Johanson R. Nifedipine in pregnancy. BJOG. 2000;107(3):299-307.

13. Papatsonis DN, Van Geijn HP, Adèr HJ, Lange FM, Bleker OP, Dekker GA. Nifedipine and ritodrine in the management of preterm labor: a randomized multicenter trial. Obstet Gynecol. 1997;90:230-4.

14. Kashanian M, Akbarian AR, Soltanzadeh M. Atosiban and nifedipine for the treatment of preterm labor. Int $\mathbf{J}$ Gynecol Obsyet. 2005;91:10-14.

15. Veet AJ, Pelink MJ, Pampus MG. Severe hypotension and fetal death due to tocolysis with nifedipine. BJOG. 2005;112:509 -10.

16. Tocolysis for women in preterm labor: RCOG green top guidelines no. 1b; February 2011.

17. de Heus R, Mol BW, Erwich JJ, van Geijn HP, Gyselaers WJ, Hanssens M, et al. Adverse drug reactions to tocolytic treatment for preterm labor: prospective cohort study. BMJ. 2009;338:b744.

18. Padovani TR, Guyyat G, Lopez LC. Nifedipine versus Terbutaline, Tocolytic Effectiveness and Maternal and Neonatal Adverse Effects: A Randomized, Controlled Pilot Trial. BCPT. 2015;116(3) 244-50.

19. Hayes E, Moroz L, Pizzi L, Baxter J. A cost decision analysis of tocolytic drugs. Am J Obstet Gynecol. 2007;197:383.e1-6.

20. Oei S. Calcium channel blockers for tocolysis: a review of their role and safety following reports of serious adverse events. Eur J Obstet Gynecol Reprod Biol. 2006;126:137-45.

21. Anotayanonth S, Subhedar NV, Garner P, Neilson JP, Harigopal S. Betamimetics for inhibiting preterm labor. Cochrane Database Syst Rev. 2004;4:CD004352.

Cite this article as: Hangekar P, Karale A, Risbud $\mathrm{N}$. Our experience of nifedipine as a tocolytic agent in preterm labor (24 weeks to 36 weeks 6 days). Int $\mathbf{J}$ Reprod Contracept Obstet Gynecol. 2017;6:636-9. 